\title{
Public-Private Sector Involvement in Providing Efficient Solid Waste Management Services in Nigeria
}

\author{
David O. Olukanni * ${ }^{\mathbb{D}}$ and Christiana O. Nwafor ${ }^{(D)}$ \\ Department of Civil Engineering, Covenant University, PMB 1022 Ota, Ogun State, Nigeria; \\ christiana.nwafor@stu.cu.edu.ng \\ * Correspondence: david.olukanni@covenantuniversity.edu.ng
}

Received: 21 February 2019; Accepted: 25 April 2019; Published: 27 April 2019

check for updates

\begin{abstract}
This paper reviews the partnership between the public and the private sectors in providing efficient solid waste management (SWM) services. While the responsibility of providing SWM services lies with the public sector, the sector has not been able to meet the demand for efficient service delivery, especially in developing countries. In a bid to increase efficiency and lower costs incurred in rendering these services, the involvement of the private sector has been sought. With a focus on major Nigerian cities, partnerships between the local government and private operators in SWM have been analysed based on the level to which the partnership has improved the SWM services. This paper provides an understanding that the success of any public-private partnership relies on the extent to which all stakeholders perform their duties. If the public sector is slack in monitoring and supervising the activities of the private operators, the latter may focus on profit generation while neglecting efficient service delivery. Also, legislation is an important part of SWM. Without the right legislation and enforcement, waste generators will not be mandated to dispose their waste properly. The public sector as a facilitator is responsible for creating an environment for private operators to function, particularly through legislation, enforcement and public sensitization.
\end{abstract}

Keywords: municipal solid waste; waste management; environmental pollution; sustainable technology; public-private partnership

\section{Introduction}

Waste management is a complex issue in developing countries, from mega-cities to small towns and villages, and has been on the priority list of successive governments, local authorities, and international donors in recent years [1,2]. This issue creates one of the most critical health and environmental concerns confronting many administrators [3-5]. In many constitutions, it is the responsibility of the local government to provide infrastructure; including power and water supplies, public transportation, telecommunications, security, and waste management facilities. As documented in the policy guidelines of the Federal Ministry of the Environment (2005) on Solid Waste Management, urban solid waste management in Nigeria is constitutionally the responsibility of the third tier of government, that is, the local government [4]. However, this tier of government has not committed the necessary financial, material, and human resources to waste management to fulfil their responsibility [6].

The actual performance of the public sector in Nigeria has left much to be desired not only in the waste management sector but in many of the state-owned enterprises which are not responsive to the changing requirements of a growing and dynamic economy and do not seem to possess the necessary tools for effective service delivery [7]. Solid waste management institutions in Nigeria are crippled by the lack of a comprehensive legislative framework for effective solid waste management, overlapping functions, lack of funding, poor implementation of environmental policy, vested interests and corruption, and a technological deficit to match the rate at which solid waste is being generated $[4,8,9]$. The people 
also have a part to play in effective SWM, as poor waste disposal habits, corruption, refusal to pay for waste collection services and bad work attitudes hinder the efforts of the local government in providing an effective waste management service in Nigeria $[4,6]$. Given the failure of the public sector in effective service delivery, many have viewed the involvement of the private sector in public infrastructure provision as a way forward. This approach has gained global prominence with varying degrees of success in different countries and in different sectors of the economy [10-15].

In view of the challenges associated with providing efficient and sustainable waste management in most urban settings in Nigeria, this paper discusses the current state of public-private partnerships (PPPs) in urban solid waste management alongside management practices and strategies. The following research questions have been drawn from the aim: In what ways can and have the private sector partnered with the public sector for more efficient service delivery? How have collaborations between the public and private sectors benefited waste management in Nigeria? What lessons can be learnt from other developing countries with relative success in jointly provided waste management services? Four cities—Lagos, Ibadan, Abuja and Port Harcourt-have been chosen from three geopolitical zones in Nigeria based on their demographic and socio-economic features as a reflection of the Nigerian situation, and because of the availability of literature on these cities.

\section{Private Sector Involvement in Infrastructure}

Private sector involvement in infrastructure development has gained significance over the years in developed and developing countries alike [16]. The local government typically represents the public partner at the national, state, or local agency level while the private partner can be a privately-owned enterprise or consortium of businesses with a particular specialisation whose main aim is profit realization [17] defines public-private partnerships (PPPs) as a contract between a public authority and one or more private operators to transfer the control of a good or a service currently provided by the public sector, either in whole or in part, to the private operators.

\subsection{Forms of Private Sector Involvement in Infrastructure}

Private sector involvement (PSI) in infrastructure development has been described as a spectrum given that it can take a number of forms, depending on the degree of risk shared by the private and public sectors and the duration of the contract. In cases where the government merely outsources the provision of a basic service to the private sector, the government retains ownership of the assets involved and a larger portion, if not all, of the risk involved. Conversely, in divestitures or privatisations, the government transfers the control of an asset either partially or in full to the private sector $[18,19]$. PPPs are considered as alternatives to full privatisation in which there is a substantial extent of risk sharing between the public and private sectors [20,21]. Table 1 gives a brief description of the basic forms of private sector involvement practiced around the world.

Table 1. Description of types of PSI with examples from other countries.

\begin{tabular}{|c|c|c|c|}
\hline & Type of PSI & Key Characteristics & Example with source \\
\hline \multirow{5}{*}{$\hat{\hat{\omega}}$} & Management Contracts & $\begin{array}{l}\text { i. Public partner owns assets and pays private contractor a service fee } \\
\text { ii. Private partner handles service delivery } \\
\text { i. Public partner owns assets } \\
\text { ii. Private partner manages operations partially or fully }\end{array}$ & $\begin{array}{l}\text { i. Waste collection and transport in } \\
\text { Bangalore, India [15] } \\
\text { i. Water and Wastewater service in } \\
\text { Amman, Jordan [11] }\end{array}$ \\
\hline & Leases & $\begin{array}{l}\text { i. Public partner leases assets to private partner and makes capital } \\
\text { investments } \\
\text { ii. Private partner manages operations and maintains facility }\end{array}$ & $\begin{array}{l}\text { i. Dar es Salaam Water Distribution } \\
\text { Company, Tanzania [19] }\end{array}$ \\
\hline & Build-Operate-Transfer (BOT) & $\begin{array}{l}\text { i. Private partner builds new facility and owns it } \\
\text { ii. Private partner operates facility } \\
\text { iii. Ownership is eventually transferred to the public partner }\end{array}$ & $\begin{array}{l}\text { i. MSW to Energy Plant in Wenzhou, } \\
\text { China [22] }\end{array}$ \\
\hline & Concession & $\begin{array}{l}\text { i. New or Existing assets owned by private partner } \\
\text { ii. Private partner operates the facility } \\
\text { iii. Ownership is eventually transferred to the public partner } \\
\text { i. Private partner buys asset from public partner }\end{array}$ & $\begin{array}{l}\text { i. Kenya-Uganda Railways, Kenya } \\
\text { and Uganda [19] }\end{array}$ \\
\hline & Divestiture/Privatisation & $\begin{array}{l}\text { ii. Private sector owns assets, makes capital investment and bears risk } \\
\text { completely }\end{array}$ & i. Thames Water, UK [10] \\
\hline
\end{tabular}


Table 1 above is not an exhaustive list of the forms of PSI that are practiced around the world. For example, the variations of the BOT contract (e.g. Build-Own-Operate, Build-Operate-Manage-Transfer), and the Private Finance Initiative (PFI) practiced in the UK are not included. Although BOT contracts and concessions share similar characteristics, they differ in the mode in which the private partner is paid. In many concession contracts, the private partner recovers its investment from the users of the service by imposing tolls, fees, etc., while BOT contracts usually involve the public sector paying a bulk fee to the private partner [21,23]. Also, because of the complexity of PSI projects, different means of classifying PSI exist, based on how the private partner recoups costs [18], and based on the nature of the service provided and the degree of risk sharing [21].

\subsection{Success Factors of Private Sector Involvement in Infrastructure Development}

Over 4000 public infrastructure projects have been implemented in collaboration with the private sector between 1990 and 2007, and a number of successes and failures have been recorded [19]. Many researchers have sought to find commonalities among PSI projects that contributed to their success or failure. One approach that has been used widely, is finding the critical success factors (CSFs) that attempt to delineate the most crucial areas that are required to ensure management success [24].

While the CSFs for PPP projects are fairly consistent around the world [25-27], the ranking of individual CSFs in developed and developing nations highlight the differences in their political and socio-economic climates. The results presented in [28] and [29] show similar CSFs for the implementation of PPP projects in Nigeria.

In Nigeria for example, the failures recorded by the state owned waste management bodies in providing non-rivalled and non-exclusive SWM service, is one of the main reasons for involving the private sector in SWM operations [4].

\section{Private Sector Involvement in SWM in Nigeria}

The Federal Ministry of Environment is responsible for environmental protection, natural resources conservation and sustainable development in Nigeria and effective waste management is one of its cardinal focuses. In 2005, a set of policy guidelines on solid waste management was developed by the Federal Ministry of Environment. The policy guidelines set out general objectives for solid waste management in Nigeria and defined the roles and responsibilities of the government at the federal-, state- and local-government level. The following four solid waste management options were recommended within the policy guidelines:

i. By local government/municipal agencies

ii. By private companies on contract with the LGA/municipality

iii. By private companies on contract with home owners

iv. By public-private partnership (PPP)

Like much of Nigeria's environmental laws and policies, the policy guidelines have never been effectively implemented, and there has not been any further development at the federal level of private sector involvement in solid waste management [30].

\subsection{Private Sector Involvement in Solid Waste Management in Abuja, Federal Capital Territory}

Abuja was created in 1976 by a decree by the then military head of state, General Murtala Mohammed. A master plan was developed for the city in 1979 that included provision of waste management infrastructure that could cater for a steady increase in population. However, due to rapid expansion, the population of Abuja now exceeds the original design capacity with a projected population of about 5.8 million people by 2026 (Federal Ministry of the Environment, 2005). Hence, waste management infrastructure has not been developed in phase with city growth and the environmental challenges of highly populated cities like Lagos are also being experienced in Abuja [31]. 
In Abuja, the Abuja Environmental Protection Board (AEPB) is responsible for the management of solid waste and is the principal authority for waste collection and disposal in the city. The area councils and satellite towns in the city were delineated into 22 lots for the purpose of daily waste collection from households in the councils. Collection of solid waste is contracted to 12 private operators in a concession agreement which runs for a minimum of three years. The AEPB, the Abuja Investment Company and a Ukrainian firm, entered into a joint-venture agreement for waste management activities in Abuja. Under the agreement, the AEPB and the Ukrainian technical partners shared the cost of procuring 50 compacting trucks and 12 street sweepers, with the AEPB contributing 20 percent of the funds. Figure 1 shows the distribution of waste management vehicles operating in Abuja and it can be seen that over $75 \%$ of operational waste management equipment is private-owned.

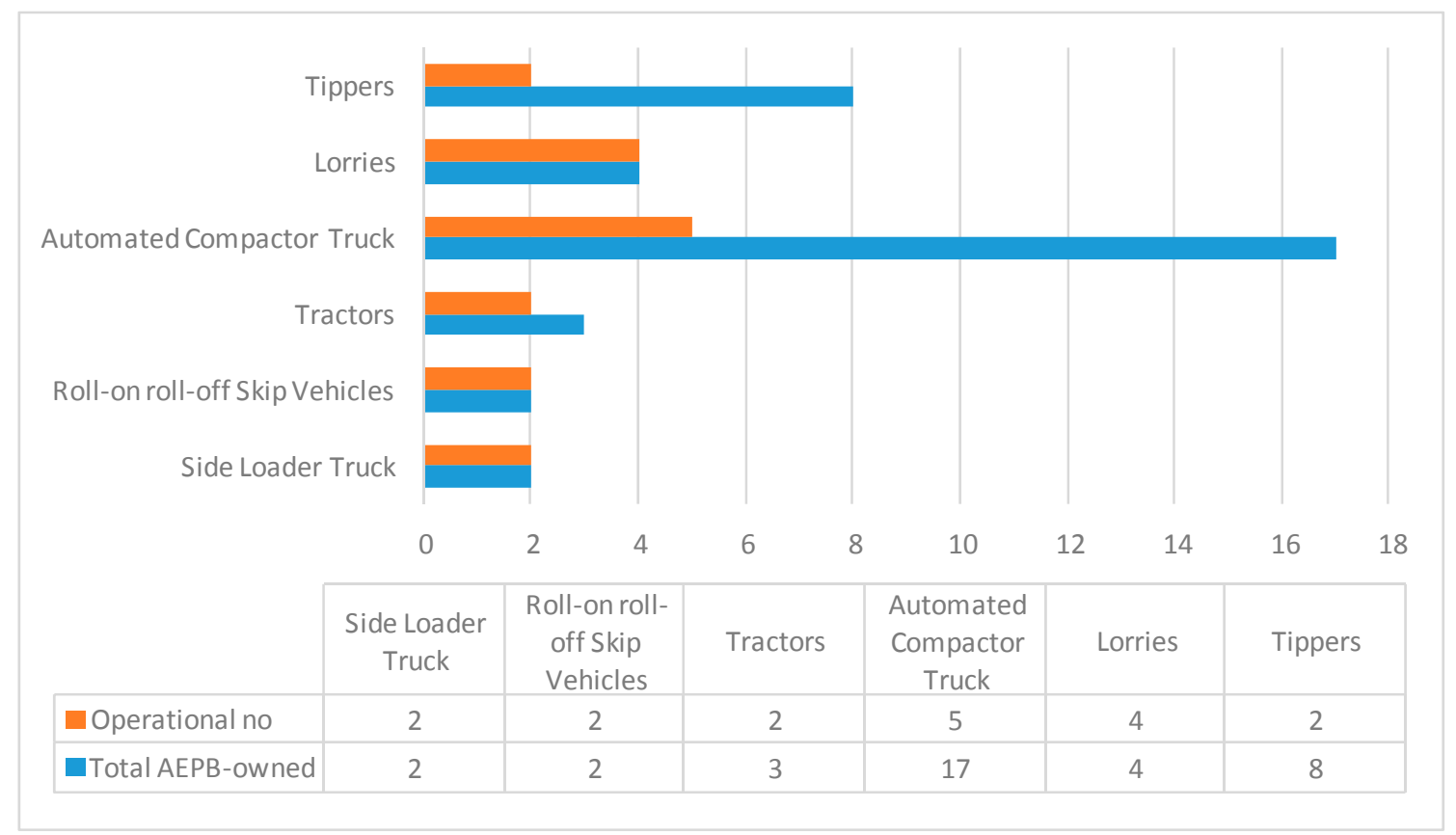

Figure 1. Distribution of waste collection, transportation and disposal vehicles in Abuja. Source: [32].

It is evident from Figure 1 that the private sector owns more operational vehicles than the public sector in Abuja due to factors such as availability of capital for procurement and maintenance of these vehicles. However, efficient waste management is still a challenge in Abuja as the service provided is usually restricted to the major districts in the city. Overflow of waste into the roads due to infrequent collection of solid waste from the designated storage sites or communal bins has been reported in some satellite towns and city suburbs.

Given the current state of waste management in the city, measures should be put in place to strengthen waste governance by integrating the private public partnership and informal sector models for more effective waste collection and disposal. This approach is expected to help reduce challenges that arise as a result of conflicts across agencies, while at the same time leveraging on the financial, technical and administrative capacity of the private sector for sustainable SWM in the city [33].

\subsection{Private Sector Involvement in Solid Waste Management in Lagos, Lagos State}

Lagos State is the economic capital of Nigeria and the largest, most diverse single settlement in the country [33]. While MSWM operations have been organized compared to other states, the management of solid waste in Lagos State is still far from optimal. Though the Nigerian constitution charges the local governments with the responsibility of SWM, over time, the state government has taken up the responsibility. 
Continuous increase in population in many cities has led to an increase in the rate of waste generation that the public agencies could not manage. The agencies lacked the financial, technological, and skilled human capital to match the rate of waste generation. This led to streets getting dirtier and exposed Nigeria to global ridicule as Lagos, the largest city in the country, became infamous for being one of the dirtiest cities in the world after the Festival of Arts and Culture in 1977 [6,34]. Even with the institution of the Lagos State Refuse Disposal Board (LSRDB) and Lagos Waste Management Authority (LAWMA) in 1977 and 1991, respectively, the state of waste management in Lagos did not improve as the medians of roads in the state were still characterized by waste heaps, drains were clogged with waste and market places and many other public places were littered with solid waste [34-36].

Prior to the incorporation of the private sector, the efforts of the government had been deterred by issues such as lack of finance for capital investments and high operational costs associated with provision of waste management service. Such problems were not peculiar to Lagos alone but were common in other states in the country. Other issues particular to the Lagos metropolis include traffic congestion which limited the number of trips collection vehicles could make per day, high rate of waste generation, unavailability of land, and rural-urban migration [37].

With 340 private sector participants (PSPs) registered in Lagos State alone, there has been an improvement in solid waste management service delivery, especially in the aspect of waste collection. The PSPs introduced waste collection at the source (that is collection from door-to-door) and residents were billed according to the value of the property and the area in the state. Residents in high income areas are billed the highest and efficiency of service delivery is reported to be highest in these areas as well [6,34]. An analysis of the state of waste management in Lagos shows that more equipment has been made available for the collection and transportation of solid waste from the source to the disposal sites.

Private sector involvement in SWM in Lagos has progressed since it was first introduced formally under the LSRDB in 1985 till 1991 when LAWMA was created. The Table 2 below outlines the history of private sector involvement in SWM in Lagos from 1997 to 2017.

Table 2. History of private sector involvement in SWM in Lagos (1997-2017).

\begin{tabular}{|c|c|c|c|}
\hline Year & SWM Institution & Advancement in SWM & Supervising Authority \\
\hline 1997-1998 & $\begin{array}{l}\text { Lagos Waste Management } \\
\text { Authority (LAWMA) and Private } \\
\text { Sector Participation (PSP) }\end{array}$ & $\begin{array}{c}\text { The private operators managed domestic waste } \\
\text { while LAWMA managed industrial, } \\
\text { commercial waste. }\end{array}$ & $\begin{array}{l}\text { Ministry of the Environment } \\
\text { and Physical Planning (MEEP) }\end{array}$ \\
\hline 2004 & Mega PSP in waste management & $\begin{array}{l}\text { PSP operators were paid monthly by the state } \\
\text { government while tenements were billed } \\
\text { monthly to recoup state funds. }\end{array}$ & $\begin{array}{l}\text { Ministry of the } \\
\text { Environment/Office of the } \\
\text { Deputy Governor }\end{array}$ \\
\hline 2007 & Mega PSP in waste management & $\begin{array}{l}\text { Procurement of additional collection trucks and } \\
\text { compactors for more efficient service delivery }\end{array}$ & LAWMA/MoE \\
\hline 2009 & $\begin{array}{l}\text { Franchised Mega PSP in waste } \\
\text { management, PPP arrangement } \\
\text { with an American firm }\end{array}$ & $\begin{array}{l}\text { Waste to compost facility sited at Ikorodu } \\
\text { where organic waste is converted to fertilizer }\end{array}$ & LAWMA/MoE \\
\hline 2015 & $\begin{array}{c}\text { Build-operate-manage-transfer } \\
\text { (BOMT) contract with West Africa } \\
\text { ENRG }\end{array}$ & $\begin{array}{l}\text { Construction and operation of the first } \\
\text { Materials Recovery Facility (MRF) in Nigeria. }\end{array}$ & LAWMA/MoE \\
\hline 2017 & $\begin{array}{l}\text { Cleaner Lagos Initiative with } \\
\text { Visionscape Sanitation Solutions }\end{array}$ & $\begin{array}{l}\text { Refurbishing, building and upgrading SWM } \\
\text { infrastructure including engineered landfills, } \\
\text { transfer loading stations, MRFs etc. }\end{array}$ & $\mathrm{MoE}$ \\
\hline
\end{tabular}

Source: [33].

While great strides have been made in the state [5], problems such as inadequate funding, cost recovery, unstable power supply, and traffic congestion militate against effective SWM in Lagos. Also, lack of continuity in implementing SWM policies prevents the full actualisation of the benefits of public-private partnerships: An example being the dissolution of LAWMA and the PSP scheme by the incumbent government. To replace them, the state government recently awarded contracts to Visionscape Sanitations Solutions and its strategic partners for deployment of waste management 
infrastructure. The transition has not been smooth, however, as the state of waste management in Lagos has since deteriorated and waste is being dumped on the streets and along the road median.

\subsection{Private Sector Involvement in Solid Waste Management in Ibadan, Oyo State}

Ibadan is the capital of Oyo State and the third most populous city in Nigeria with 3,088,477 residents [38]. The city is one of the foremost commercial hubs in Nigeria alongside Kano and Onitsha. The Oyo State Solid Waste Management Authority (OYOMWA) is responsible for waste management in the Ibadan metropolis. Managing the large volumes of waste generated in Ibadan has been a serious challenge for all stakeholders. Indiscriminate dumping of waste is widely practiced in the city resulting in waste heaps littering road sides and streets.

Private sector involvement in SWM in Ibadan dates as far back as 1994 when private contractors were involved in collection, transport, and disposal of solid waste [30,31]. In Oyo State, the private sector participation scheme suffered because of challenges with availability of capital for the purchase of equipment. Therefore, purchasing equipment for use such as trucks and tippers is always beyond the reach of the owners. The resultant effect of this constraint was that some firms also used their trucks for construction activities in order to maximize profit. Also due to financial constraints, the private firms are unable to purchase the necessary spare part replacements, pay staff salary and employ trained experienced manpower [39].

\subsection{Private Sector Involvement in Solid Waste Management in Port Harcourt, Rivers State}

Port Harcourt is the capital city of Rivers State and one of the most prominent cities in the southern region of Nigeria. Port Harcourt was initially established as a port-town during the colonial times but since the discovery of oil in Rivers State, the city has evolved into one of great economic and political importance. The city is home to 1,845,232 residents [38]; a number which is rapidly on the increase due to urbanization and rural-urban migration.

The Rivers State Waste Management Agency (RIMAWA) is responsible for solid waste management in the state under the supervision of the state Ministry of Environment. The agency engages about 88 local vendors or contractors who provide services ranging from de-silting of creeks and canals, municipal waste collection, and dumpsite management within Rivers State (RIMAWA, n.d.). The challenges of managing waste in Port Harcourt arose mainly with the uncontrolled and unplanned development of the city which resulted in overcrowding, unplanned road networks, and heaps of refuse littering various parts of the city [40]. House-to-house collection is limited to the elite areas of the city (e.g. Old GRA) while communal bins are provided in areas like Borokiri [41]. A study carried out by Stanley and Owhor [41] on 390 respondents in three neighbourhoods within the city showed that the frequency of collection also varied across the city with Ogbumnuabali enjoying more frequent collection than Borokiri and Elekahia. The above data points to the fact that waste collection is not uniform in the city even with the involvement of private contractors.

Comparing the state of solid waste management in Lagos and Port Harcourt, it is evident that the latter is only beginning to explore the benefits of collaborating with the private sector for more efficient service delivery. Waste management in Rivers State is still in its developmental stages and is mainly concerned with collection, transportation and disposal of solid waste. No attention has been given formally to waste minimization activities or the recovery of resources from the waste stream.

\section{Conclusions}

While there are many opportunities in private sector involvement, it should not be seen as a panacea-a supposed cure for all problems. In fact, partnerships with the private sector can worsen the state of SWM if all the stakeholders involved are not committed to fulfilling their distinct roles. The role of the public sector changes from direct involvement in construction and service provision, to ensuring that the PPP delivers value for money for the government and better services for users. In Lagos, unlike other cities in Nigeria, many of the partnerships with the private sector in SWM 
are with agencies with an understanding of standard SWM practices and the financial and technical capacity to deliver services efficiently.

Solid waste management in many developing countries especially Nigeria is not where it ought to be. Lapses in collection, treatment and disposal militate against the effective management of waste generated in many major cities. Relying on public-private partnerships (PPPs) without providing the necessary legal and institutional framework will not produce the desired results in effective SWM.

\section{Recommendation}

The World Bank recommends that cost recovery of waste management services should be ensured and the revenue collection of waste management fees from waste producers should be increased [31]. Also, a transparent procurement process for private sector participants should be established and performance-based contracts should be developed. The government should include the people in the decision making process to foster acceptance of new policies and initiatives. Finally, the act of keeping the environment safe and clean by proper disposal of wastes can be enhanced if regulatory measures are enforced on the people. In lieu of this, public health officers (PHOs) need to enforce compliance with these regulations by the residents. This will go a long way in achieving sustainable waste management because people will not want to be victims of law for fear of the penalty attached to it $[28,39]$.

Author Contributions: Conceptualization of the research work came from D.O.O. and the methodology adopted was carried out by the authors: D.O.O. and C.O.N. All the authors played a contributing role in the use of the software, and the validation of the work was carefully checked by D.O.O. The formal analysis and investigation was done by D.O.O. Resources and data curation was carried out by D.O.O., and C.O.N. While the writing of original draft preparation was done by D.O.O. and C.O.N. Writing-review editing was done by D.O.O. Visualization, supervision and project administration was done by D.O.O.

Funding: This research received no external funding.

Acknowledgments: The authors are grateful to the management of Covenant University for providing an enabling environment in doing the report of this research work. We also appreciate the various authors of resource materials that were used which provided relevant information that led to the success of this work.

Conflicts of Interest: The authors declare no conflict of interest.

\section{References}

1. Hoornweg, D.; Bhada-Tata, P. What a Waste: A Global Review of Solid Waste Management; World Bank, Urban Development Series; Knowledge Papers No. 15; The World Bank eLibrary: Washington, DC, USA, 2012.

2. Olukanni, D.O. Analysis of municipal solid waste management in Ota, Ogun State, Nigeria: Potential for wealth generation. In Proceedings of the International Conference on Solid Waste Management (ICSW), Philadelphia, PA, USA, 10-13 March 2013; pp. 184-196.

3. Olukanni, D.O.; Aremu, D.O. Provisional Evaluation of Composting as Priority Option for Sustainable Waste Management in South-West Nigeria. Pollution 2017, 3, 417-428. [CrossRef]

4. Olukanni, D.O.; Adeleke, J.O.; Aremu, D.D. A Review of Local Factors Affecting Solid Waste Collection in Nigeria. Pollution 2016, 2, 339-356. [CrossRef]

5. Olukanni, D.O.; Oresanya, O.O. Progression in Waste Management Processes in Lagos State, Nigeria. Int. J. Eng. Res. Africa 2018, 35, 11-23. [CrossRef]

6. Anestina, A.I.; Adetola, A.; Odafe, I.B. Performance Assessment of Solid Waste Management following Private Partnership Operations in Lagos State, Nigeria. J. Waste Manag. 2014, 2014, 1-8. [CrossRef]

7. Asaolu, T.O. Privatization in Nigeria: Regulation, deregulation, corruption and the way forward. In Inaugural Lecture Delivered at Oduduwa Hall, Obaremi Awolowo Univeristy, Ile-Ife; Obafemi Awolowo University Press Limited: Ile-Ife, Osun, Nigeria, 2015; Available online: http://thenationonlineng.net/privatization-in-nigeriaregulation-deregulation-corruption-and-the-way-forward (accessed on 27 April 2019).

8. Abila, B.; Kantola, J. Municipal Solid Waste Management Problems in Nigeria: Evolving Knowledge Management Solution. Int. J. Environ. Ecol. Geol. Min. Eng. 2013, 7, 169-174. 
9. Ezeah, C.; Roberts, C.L. Analysis of barriers and success factors affecting the adoption of sustainable management of municipal solid waste in Nigeria. J. Environ. Manag. 2012, 103, 9-14. [CrossRef] [PubMed]

10. Delmon, J. Understanding Options for Private-Partnership Partnerships in Infrastructure: Sorting out the Forest from the Trees: BOT, DBFO, DCMS, Concession, Lease ... ; The World Bank eLibrary: Washington, DC, USA, 2010. [CrossRef]

11. Marin, P. Public-Private Partnerships for Urban Water Utilities: A Review of Experiences in Developing Countries; The World Bank eLibrary: Washington, DC, USA, 2010.

12. Spoann, V.; Fujiwara, T.; Seng, B.; Lay, C.; Yim, M. Assessment of Public-Private Partnership in Municipal Solid Waste Management in Phnom Penh, Cambodia. Sustainability 2019, 11, 1228. [CrossRef]

13. Wiafe, M. Private Sector Involvement in Solid Waste Management in the Kumasi Metropolitan Assembly. Master's Thesis, Kwame Nkrumah University of Science and Technology, Kumasi, Ashanti, Ghana, 2014. Available online: http://dspace.knust.edu.gh/bitstream/123456789/8068/1/MAXYFT\%282\%29final.pdf (accessed on 27 April 2019).

14. Yescombe, E.R. Public-Private Partnerships in Sub-Saharan Africa: Case Studies for Policymakers. Available online: https:/www.africaportal.org/publications/public-private-partnerships-sub-saharan-africa-casestudies-policymakers-2017/ (accessed on 20 April 2018).

15. Zhu, D.; Asani, P.U.; Zurbrugg, C.; Anapolsky, S.; Mani, S. Improving Municipal Solid Waste Management in India, A Sourcebook for Policy Makers and Practitioners; WBI Development Studies; World Bank: Washington, DC, USA, 2008. [CrossRef]

16. Akintoye, A. PPPs for Physical Infrastructure in Developing Countries. In Policy, Finance E Management for Public-Private Partnerships; Wiley-Blackwell: Oxford, UK, 2009; pp. 123-144. [CrossRef]

17. Massoud, M.; El-Fadel, M. Public-private partnerships for solid waste management services. Environ. Manag. 2002, 30, 621-630. [CrossRef] [PubMed]

18. Farquharson, E.; Torres de Mästle, C.; Yescombe, E.R. How to Engage with the Private Sector in Public-Private Partnerships in Emerging Markets; The World Bank eLibrary: Washington, DC, USA, 2011. [CrossRef]

19. Yong, H.K. Public-Private Partnerships Policy and Practice: A Reference Guide; Yong, H.K., Ed.; The Commonwealth iLibrary: London, UK, 2010. [CrossRef]

20. Ahmed, S.A.; Ali, M. Partnerships for solid waste management in developing countries: Linking theories to realities. Habitat Int. 2004, 28, 467-479. [CrossRef]

21. Yescombe, E.R. Public-Private Partnerships: Principles of Policy and Finance; Elsevier: Amsterdam, The Netherlands, 2007.

22. Asian Development Bank. Municipal Solid Waste treatment: Case Study of Public-Private Partnerships (PPPs) in Wenzhou. 2010. Available online: https://www.adb.org/publications/municipal-solid-wastetreatment-case-study-ppps-wenzhou (accessed on 21 March 2019).

23. World Bank. Public-Private Partnerships Reference Guide V 2.0; The World Bank Group: Washington, DC, USA, 2014.

24. Muhammad, Z.; Sik, K.K.; Johar, F.; Sabri, S. An overview of critical success factors of publicprivate partnership in the delivery of urban infrastructure and services. Plan. Malays. J. 2016, 14, 147-162.

25. Chou, J.S.; Pramudawardhani, D. Cross-country comparisons of key drivers, critical success factors and risk allocation for public-private partnership projects. Int. J. Proj. Manag. 2015, 33, 1136-1150. [CrossRef]

26. Osei-Kyei, R.; Chan, A.P.C. Comparative Analysis of the Success Criteria for Public-Private Partnership Projects in Ghana and Hong Kong. Proj. Manag. J. 2017, 48, 80-92. [CrossRef]

27. Osei-Kyei, R.; Chan, A.P.C. Empirical comparison of critical success factors for public-private partnerships in developing and developed countries A case of Ghana and Hong Kong. Eng. Constr. Archit. Manag. 2017, 24, 1222-1245. [CrossRef]

28. Sanni, A.O. Factors determining the success of public private partnership projects in Nigeria. Constr. Econ. Buil. 2016, 16, 42-55. [CrossRef]

29. Babatunde, O.S.; Opawole, A.; Akinsiku, E.O. Critical success factors in public-private partnership (PPP) on infrastructure delivery in Nigeria. J. Facil. Manag. 2012, 10, 212-225. [CrossRef]

30. Onibokun, A.G. Managing the Monsters: Urban Waste and Governance in Africa; IDRC Books: Ottawa, ON, Canada, 1999. 
31. World Bank. Private Sector Participation in Solid Waste Management Activities in Ibadan, Nigeria; The World Bank Group: Washington, DC, USA, 2017; Available online: http://documents.worldbank.org/curated/ en/221251487249039986/Nigeria-Private-sector-participation-in-solid-waste-management-activities-inIbadan-synthesis-note (accessed on 27 April 2019).

32. Imam, A.; Mohammed, B.; Wilson, D.C.; Cheeseman, C.R. Solid waste management in Abuja, Nigeria. Waste Manag. 2008, 28, 468-472. [CrossRef]

33. Ezeah, C.; Roberts, C.L. Waste governance agenda in Nigerian cities: A comparative analysis. Habitat Int. 2014, 41, 121-128. [CrossRef]

34. Adedibu, A.A.; Okekunle, A.A. Issues in the environmental sanitation of Lagos mainland, Nigeria. Environmentalist 1989, 9, 91-100. [CrossRef]

35. Aliu, I.R.; Adeyemi, O.E.; Adebayo, A. Municipal household solid waste collection strategies in an African megacity: Analysis of public private partnership performance in Lagos. Waste Manag. Res. 2014, 32 (Suppl. 9), 67-78. [CrossRef] [PubMed]

36. Adeniran, A.E.; Nubi, A.T.; Adelopo, A.O. Solid waste generation and characterization in the University of Lagos for a sustainable waste management. Waste Manag. 2017, 67, 3-10. [CrossRef]

37. Ayantoyinbo, B.; Adepoju, O. Analysis of Solid Waste Management Logistics and Its Attendant Challenges in Lagos Metropolis. Logistics 2018, 2, 11. Available online: www.africapolis.org/data (accessed on 5 February 2019). [CrossRef]

38. Alakinde, M.K. Private sector participation and sustainable solid waste management in Ibadan South West Local Government, Nigeria. J. Emerg. Trends Econ. Manag. Sci. 2012, 3, 887-892.

39. Ayotamuno, J.M.; Gobo, A.E. Municipal solid waste management in Port Harcourt, Nigeria: Obstacles and prospects. Manag. Environ. Qual. 2004, 15, 389-398. [CrossRef]

40. Ikebude, C.F. Feasibility Study on Solid Waste Management in Port Harcourt Metropolis: Causes, Effects and Possible Solutions. Niger. J. Technol. 2017, 36, 276-281. [CrossRef]

41. Stanley, H.; Owhor, A. Assessment of Solid Waste Management Practice in Port Harcourt Metropolis, Rivers State, Nigeria. J. Geogr. Environ. Earth Sci. Int. 2018, 16, 1-10. [CrossRef]

(C) 2019 by the authors. Licensee MDPI, Basel, Switzerland. This article is an open access article distributed under the terms and conditions of the Creative Commons Attribution (CC BY) license (http://creativecommons.org/licenses/by/4.0/). 